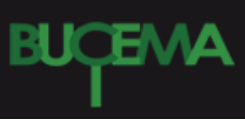

Bulletin du centre d'études médiévales d'Auxerre | BUCEMA

Hors-série $n^{\circ} 8 \mid 2015$

Au seuil du cloître : la présence des laïcs (hôtelleries, bâtiments d'accueil, activités artisanales et de services) entre le Vé et le XII ${ }^{\mathrm{e}}$ siècle

\title{
Is there an archaeology of lay people at early Irish monasteries?
}

Tomás Ó Carragáin

\section{OpenEdition \\ Journals}

Édition électronique

URL : https://journals.openedition.org/cem/13620

DOI : $10.4000 /$ cem. 13620

ISSN : 1954-3093

Éditeur

Centre d'études médiévales Saint-Germain d'Auxerre

Référence électronique

Tomás Ó Carragáin, «Is there an archaeology of lay people at early Irish monasteries ? », Bulletin du centre d'études médiévales d'Auxerre | BUCEMA [En ligne], Hors-série n 8 | 2015, mis en ligne le 16 novembre 2015, consulté le 02 mars 2023. URL : http://journals.openedition.org/cem/13620 ; DOI : https://doi.org/10.4000/cem.13620

Ce document a été généré automatiquement le 2 mars 2023

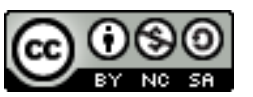

Creative Commons - Attribution - Pas d'Utilisation Commerciale - Partage dans les Mêmes Conditions 4.0 International - CC BY-NC-SA 4.0

https://creativecommons.org/licenses/by-nc-sa/4.0/ 


\title{
Is there an archaeology of lay people at early Irish monasteries?
}

\author{
Tomás Ó Carragáin
}

1 The theme of this collection of papers is an important one which, in the Irish context, raises interesting questions of definition that go far beyond mere semantics. For example, what exactly do we mean by the term "monastery" in this period and is it possible to identify such sites archaeologically? Beyond that, is it possible to identify lay people among

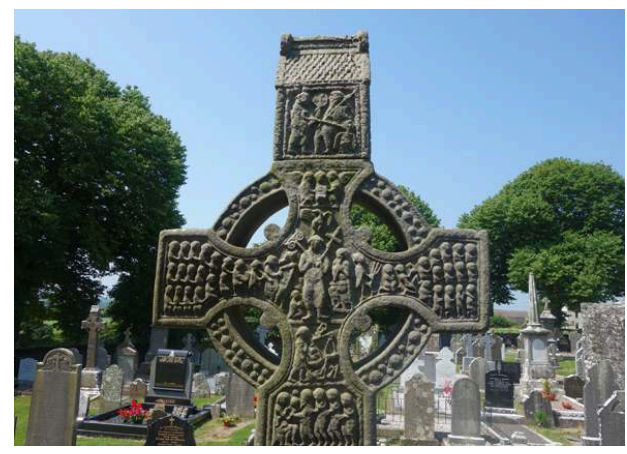
those visiting, living and working at these sites? Can certain archaeologicallyattested activities be taken as evidence for the presence of lay people or might they just as easily have been carried out by people which, to a greater or lesser extent, were commitment to the religious life? This general, and by no means exhaustive, paper aims to address these issues in a way which it is hoped will be useful, especially to colleagues who are not familiar with the Irish material.

2 There have been major changes in recent years in our understanding of the organisation of ecclesiastical power structures in Ireland ${ }^{1}$. The traditional view was that early Irish churches were overwhelmingly monastic in character, but now it is recognised that only a small minority of the thousands of churches established in Ireland were monasteries in the usual sense of the term. Many of them were community or family churches served (sometimes only occasionally) by a priest, rather than by a community of monks (fig. 1). 
Fig. 1 - Carte des sites monastiques cités dans l'article.

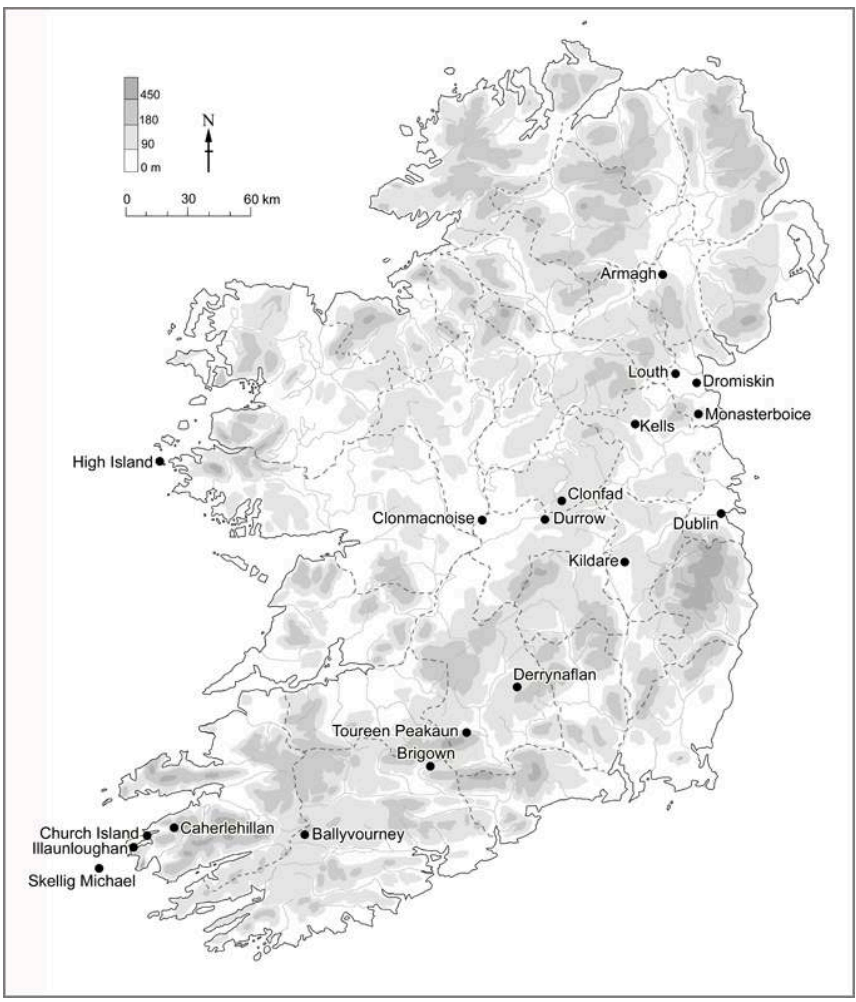

3 In the case of these fairly minor sites, it is often difficult to determine their character because of limited documentary coverage and ambiguous archaeology. Architecture does not supply ready indications, for the specifically monastic architecture developed in Carolingian Europe had little discernible impact in Ireland until the twelfth century ${ }^{2}$. Segregated burial is potentially the least ambiguous archaeological indicator, but very few ecclesiastical cemeteries have been extensively excavated and analysed.

4 The founders of the most important sites, such as Armagh and Clonmacnoise, were conceived of as ascetic monastic figures ; but, whatever their initial character, most of these sites became multi-functional with a resident bishop in addition to a variety of religious communities (fig. 2). 
Fig. 2 - Clonmacnoise from the southwest. Evidence for extensive craft activity was uncovered in the New Graveyard, east (right) of the main complex (Photo courtesy of the National Monuments Service, Department of Arts, Heritage and the Gaeltacht, Ireland).

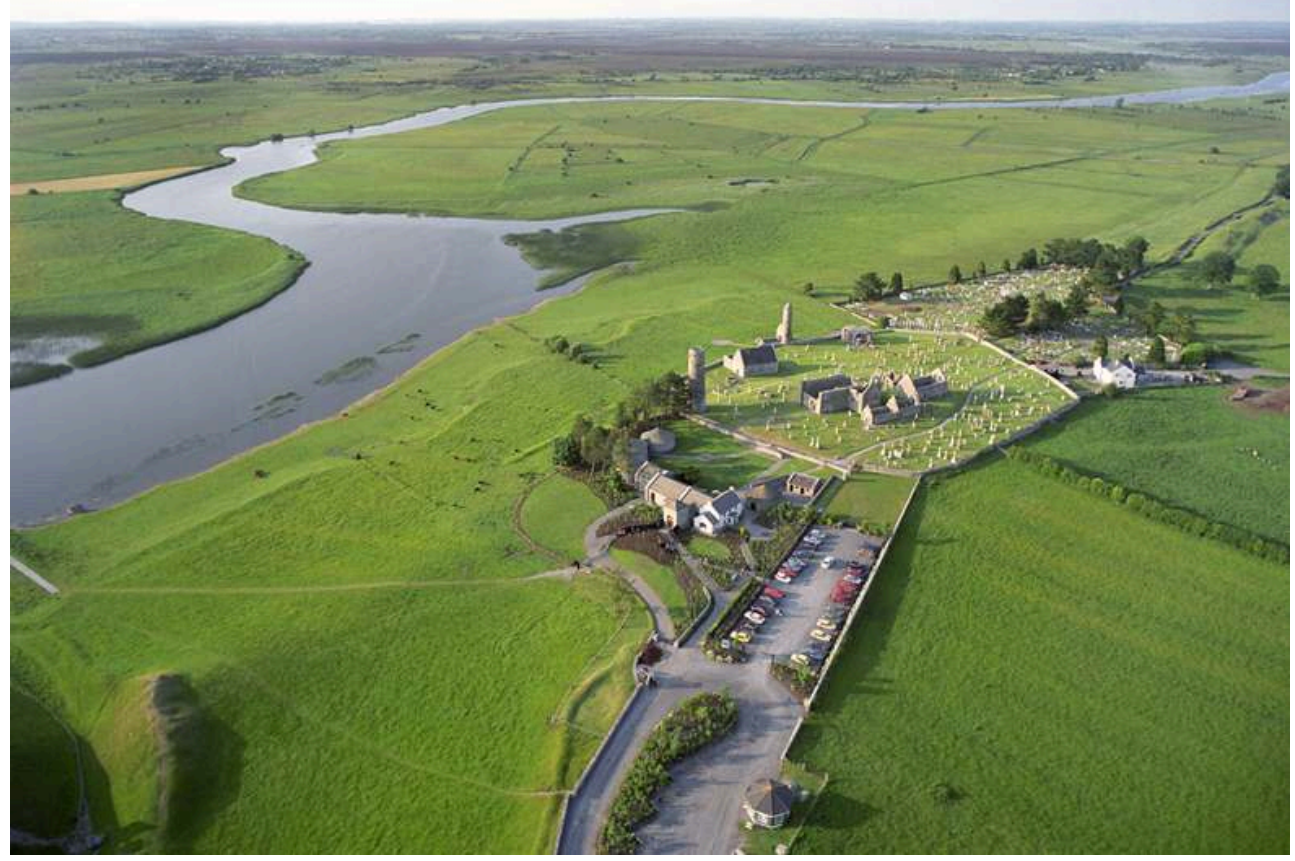

5 Arguably, then, it is unhelpful to refer to them as monasteries, and indeed they were rarely referred to as such in contemporary sources : civitas was a more common term ${ }^{3}$. Partly because of the use of such terminology, a number of scholars in the 1980s argued that the major sites became urban or proto-urban "monastic towns " ${ }^{4}$; but more recently this idea has fallen out of favour ${ }^{5}$. Interestingly some scholars have also expressed a degree of scepticism about the role of monasteries as drivers towards urbanism elsewhere in Europe ${ }^{6}$. Notwithstanding their undoubted economic importance as productive and sometimes nucleated settlements, their role as centres of trade has sometimes been over-emphasised. For example, contrary to earlier suggestions, it has recently been argued that the so-called market crosses at some of these sites only became the focus of market activity in the later medieval period 7 . Similarly, while many additional subsidiary churches were erected at major sites in the tenth and eleventh centuries, they do not form parochial networks like those rapidly developing in fully fledged urban centres abroad and in the Hiberno-Scandinavian ports. Instead, many of them are associated with particular groups of religious such as nuns or the ascetic Céli Dé and so are more likely to reflect factors such as royal patronage and the diversification of religious communities rather than the need to provide parish churches for burgeoning lay communities ${ }^{8}$.

6 So where does that leave us in terms of identifying the laity at ecclesiastical sites that had a substantial monastic component? There is abundant documentary evidence that significant numbers of lay people spent time at ecclesiastical sites as pilgrims, penitents, patients, paupers, travellers and seekers of sanctuary ${ }^{9}$. There is also documentary evidence that some lay people were buried at monastic sites and some sites feature satellite cemeteries apparently for certain sections of the laity ${ }^{10}$. References to Hiberno-Scandinavians at Monasterboice, Louth and Dromiskin has been 
interpreted as evidence for the billeting of troops at strategically important ecclesiastical sites ${ }^{11}$. While some hagiography and monastic Rules imply that the laity should be excluded, texts such as the early eighth century Collectio Canonum Hibernensis indicate lay access, at least to the outer precincts of important church sites ${ }^{12}$. Cogitosus' Life of St Brigit implies that, already by the late seventh-century, major sites were attracting significant numbers of pilgrims; and there is archaeological evidence for the development of suites of pilgrimage monuments at sites such as Inishmurray in the latter part of the early medieval period ${ }^{13}$. The provision of hospitality both to ecclesiastics and the laity was, of course, an important duty of monastic communities. Guest houses are frequently mentioned in the early sources and possible examples have been identified at sites such as Church Island, Skellig Michael and High Island based on their locations immediately outside the main enclosure ${ }^{14}$, though it should be noted that the Church Island example may pre-date the enclosure ${ }^{15}$. According to hagiography, lay people were expected to live a paramonastic existence during such stays ${ }^{16}$. Some penitents and those with chronic diseases were accommodated on a permanent basis ${ }^{17}$, and it has been argued that a number of extant churches, such as Temple Ciarán, Clonmacnoise, and St Columba's, Kells, were originally foci for complexes associated with the care of the poor and the sick as well as with relics and ascetics (fig. 3) ${ }^{18}$.

Fig. 3 - St Columba's House, Kells. This late eleventh century church appears to have been part of a complex, within the monastery of Kells, associated with care of the sick (Photo T. Ó Carragáin).

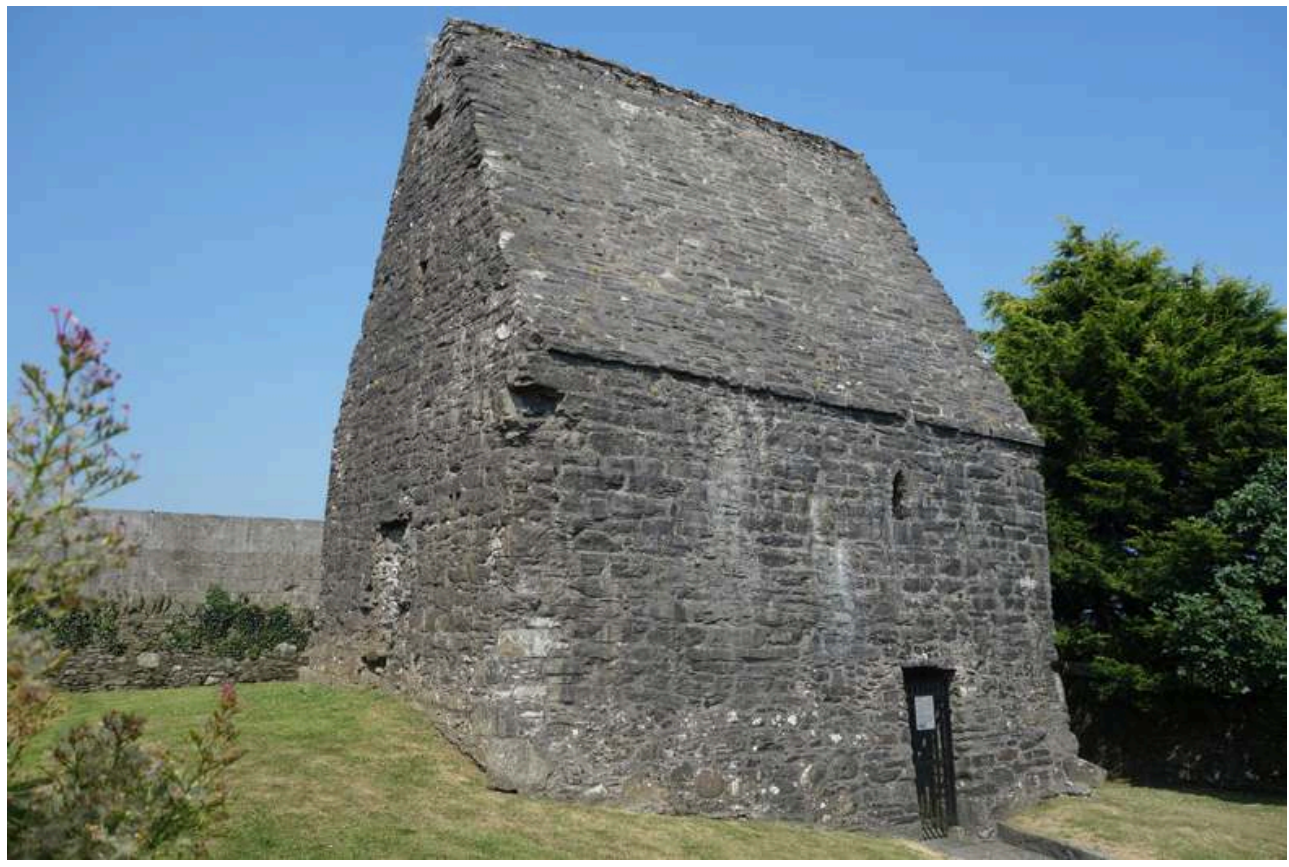

\section{Craft activity at ecclesiastical sites}

7 Here, however, I wish to focus on the question of whether or not substantial numbers of able-bodied lay people were accommodated at or near monasteries on a permanent basis. This is not an easy question to answer from an archaeological perspective. The excavation of domestic and craft activity outside the sacred cores (innermost enclosures) of major sites such as Clonmacnoise and Armagh might be seen as 
supporting the idea ; but this evidence can be interpreted in a number of ways and in general excavated remains do not usually allow us to distinguish between laity and religious with any confidence.

All extensively excavated ecclesiastical sites have produced some evidence for craft activity. While some were generic activities which one would also expect to find at lay settlements such as ringforts, others were intrinsic to the ecclesiastical/monastic character of these sites. An example of the former is the evidence for black-smithing uncovered at the monastery of Toureen, Co. Tipperary, which was probably for the manufacture and repair of everyday tools (fig. 4) ${ }^{19}$.

Fig. 4 - Eighth-century smithing hearth (left) excavated at the monastery of Toureen Peakaun, Co. Tipperary. The rectangular patch of dark material on the right may have accumulated in a hollow created by an anvil base (Photo T. Ó Carragáin).

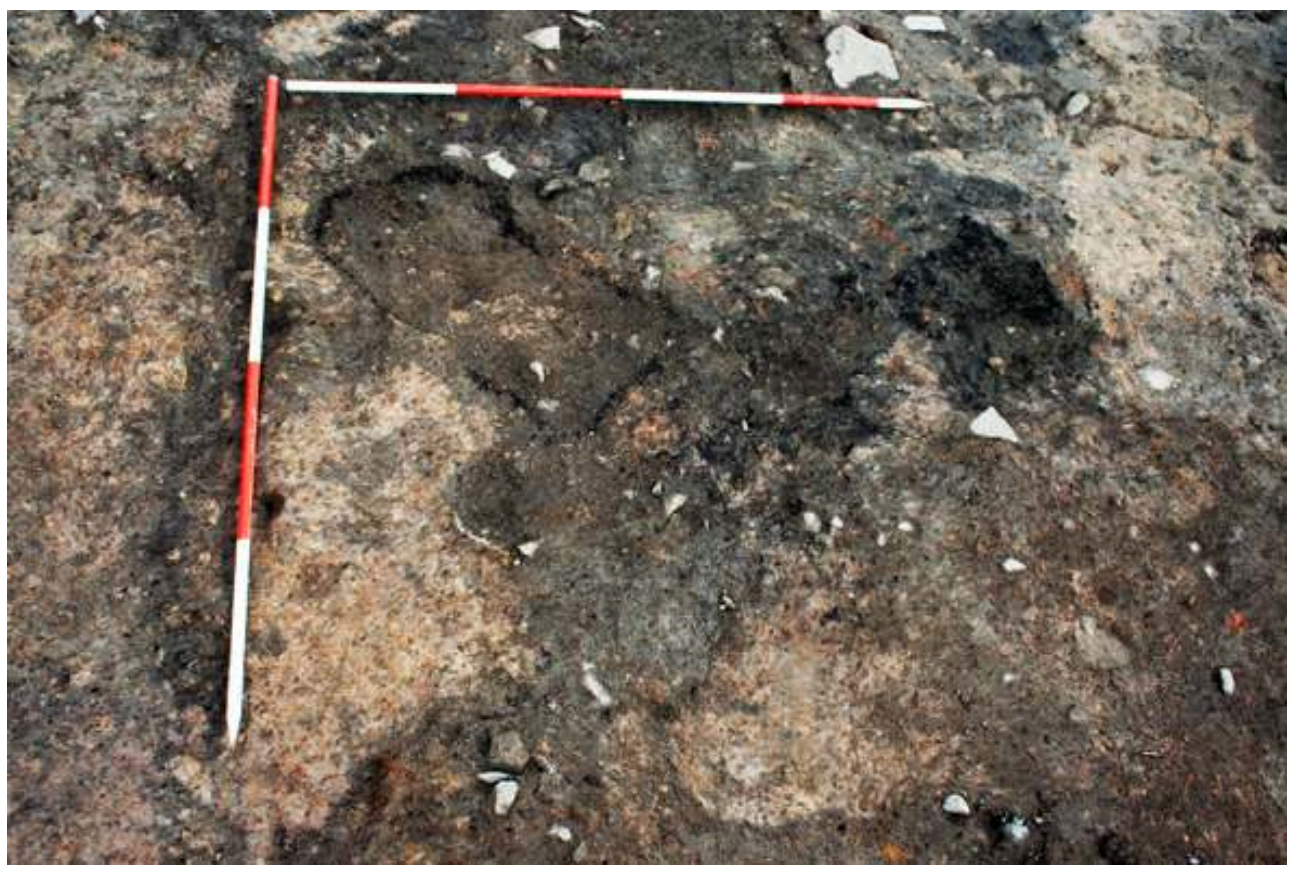

9 An example of the latter is sculpture, which was also produced at Toureen and which, at a few sites like Clonmacnoise, was produced on quite a large scale at certain times, with the production of many of the minor pieces (grave-slabs etc.) probably coinciding with the commissioning of monumental high crosses, especially in the ninth and early tenth centuries ${ }^{20}$. Another craft particular to ecclesiastical sites is the production of vellum, which is best attested archaeologically at Portmahomack, a Pictish monastery on the east coast of Scotland excavated by Martin Carver ${ }^{21}$. Rows of cattle metapodials set vertically in the ground were interpreted as pegs from a vanished wooden stretcher for preparing vellum, and there was also a lined tank for tanning leather and sea shells to produce a light colour suitable for vellum. There were also several objects associated with leather and possibly vellum manufacture, including a crescent-shaped knife and bone needles and pieces of volcanic lava that might have been for smoothing and finishing fine leather.

10 Another obvious case is the production of ecclesiastical metalwork. One of the most common items of ecclesiastical metalwork to survive in Ireland is the hand bell. They are preserved in relatively large numbers because they came to be considered 
associative relics of the founding saints. Paul Stevens' landmark publication of his excavations at Clonfad, Co. Westmeath has given us a stunning insight into the processes surrounding the production and distribution of such bells ${ }^{22}$. Clonfad was chief church of the southern half of the kingdom of Fir Tulach ${ }^{23}$. It was established in the sixth century and excavation of its eastern periphery produced features dating mainly from the sixth to the ninth century ${ }^{24}$. A linear ditch, possibly representing an original enclosure, was superseded by the inner of two enclosing ditches. The outer one seems to have been dug in the seventh century and both were deliberately filled during the ninth or more likely the eighth century ${ }^{25}$. There was evidence for iron-working at the site from the beginning and it produced one of the biggest deposits of iron slag from any early medieval Irish site (1.5 tonnes), as well as evidence for a substantial rectangular blacksmith's forge ${ }^{26}$. There was little evidence for smelting. Instead the ironworking took the form of primary and secondary smithing, especially the manufacture of iron handbells, each of which was produced from a single large sheet of iron. Most importantly Clonfad has produced the earliest evidence to date from early medieval Europe for the clay shrouds used to cover the iron bell during the brazing process, whereby a veneer of copper-alloy was added to its surface ${ }^{27}$. The stratigraphic contexts of the shroud fragments suggests that bells were produced at different times over a considerable period, possibly to supply churches across a wide area ${ }^{28}$. As at Clonmacnoise ${ }^{29}$, the faunal remains recovered suggests that the site was primarily a consumer rather than a producer of cattle ${ }^{30}$. Significantly, however, there is no suggestion that Clonfad was an urban site. Indeed, despite its regional importance there is no evidence that it even became nucleated; and if anything the infilling of enclosures suggests a contraction of the extent of the settlement after the eighth century.

11 How are we to interpret this craft activity in the context of the theme of this collection? The first thing to emphasise, of course, is that one interpretation most certainly does not fit all. We have evidence for a wide range of activity in terms of character, diversity, chronology and intensity. The question is, is any of it likely to have been carried out with the involvement of people who might usefully be described as belonging to the laity? First of all, it is important to make a distinction between activities involving limited skills on the one hand and highly-skilled manufacturing such the bell-manufacturing at Clonfad on the other. In considering who might be responsible for the latter, we will discuss three possible models: the non-resident craftsperson, the resident craftsperson, and the clerical/monastic craftsperson. In reality things are unlikely to have been so rigid. There were probably overlaps between these different categories, and they may have applied, to a greater or lesser extent, depending on the site and crafts in under discussion. In the following discussion we will focus in particular on fine metalworking.

\section{The non-resident craftsperson}

Some have argued that many craftspeople were itinerant or peripathetic, wandering between sites seeking work ${ }^{31}$. It has been suggested that the homogeneity of the style and decorations of pins and brooches supports this model ${ }^{32}$. It is important to emphasise, however, that there is not an absolute correlation between the degree of uniformity of objects on the one hand and the extent to which their makers travelled 
on the other. Ethnoarchaeological work by Ian Hodder has shown that a travelling craftsperson could produce a considerable variety of forms, while local craftspeople could produce uniform forms over wide areas, depending on the requirements of those commissioning the pieces and the cultural context in which they are produced ${ }^{33}$.

Most of the documentary evidence points to stationary workshops ${ }^{34}$, but the laws make provision for the likelihood that craftspeople had to move about ${ }^{35}$. The Uraicecht Becc stipulates that, unlike the general population, craftspeople were allowed to travel between kingdoms (túatha) and that they were assured of protection: «Every art [...] that is entitled to franchise, the franchise that he has in the "tuath" does not fail for want of his art if he practise it elsewhere, be it in a "tuath" or in a church ${ }^{36}$. " A number of sections of the eighth century Collectio Canonum Hibernensis refer to the payment of wages to labourers "from the property of the [church] site (locus) ${ }^{37}$ ". While it is not specified, some of these labourers could be craftspeople; and other law tracts deal with the payments and refection due to the saer (wright) and his followers for the construction of buildings ${ }^{38}$. There are also several episodes in hagiography, however, in which monks refuse hospitality to artists and craftspeople, who are portrayed as parasites and sinners ${ }^{39}$.

It has reasonably been argued that lesser sites with modest evidence for metalworking could not sustain a craftsperson on a permanent basis. For example, the excavators argued that the fine metalwork on Illaunloughan was produced by a travelling artisan (fig. 5) ${ }^{40}$.

Fig. 5 - Bone trial piece for metalworking and clay mould fragments, Illaunloughan, Co. Kerry. From J. White Marshall and C. Walsh, Illaunloughan Island, Bray, 2005, Figs. 13 and 102.

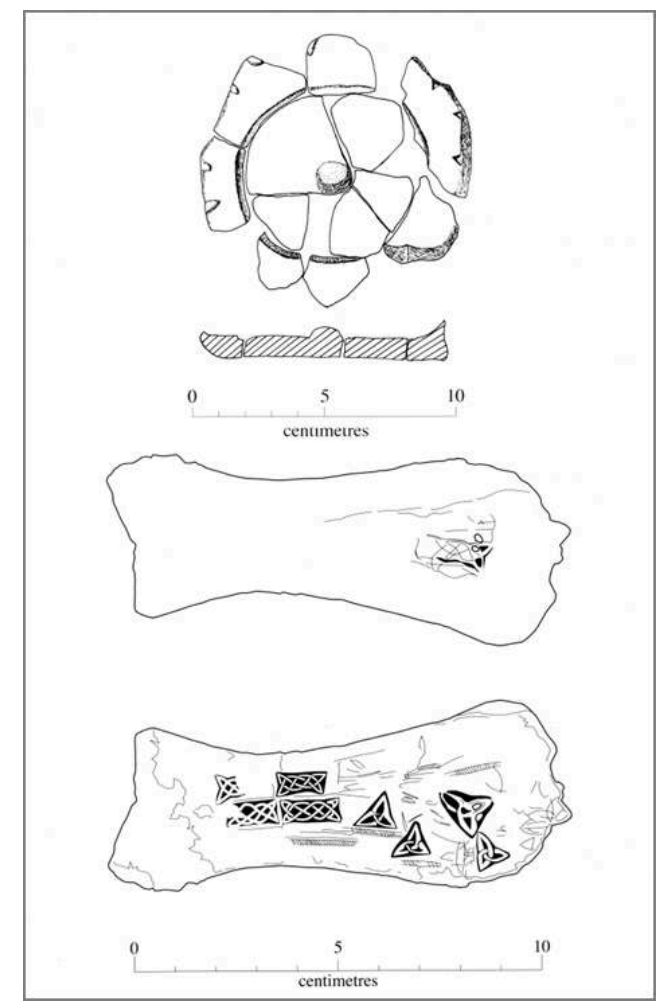

15 It should be pointed out that this site has been extensively eroded, making it difficult to judge the extent of metalworking. We should also allow for the possibility that in some 
cases metalworking was part-time activity rather than a full-time occupation ${ }^{41}$; and McCarthy has discussed the possibility that the Illaunloughan metalworking was undertaken by members of the monastic community ${ }^{42}$. Nonetheless, it is the major sites that are most likely to have sustained « resident » craftspeople.

There is also evidence that particular craftspeople, or groups of craftspeople, moved about between important sites. For example, in the eleventh to early twelfth century, wooden churches were quite commonly replaced by stone ones in certain parts of Ireland (fig. 6).

Fig. 6 - Pre-Romanesque church, Kiltiernan, Co. Galway. Probably eleventh or early twelfth century (Photo J. O'Sullivan).

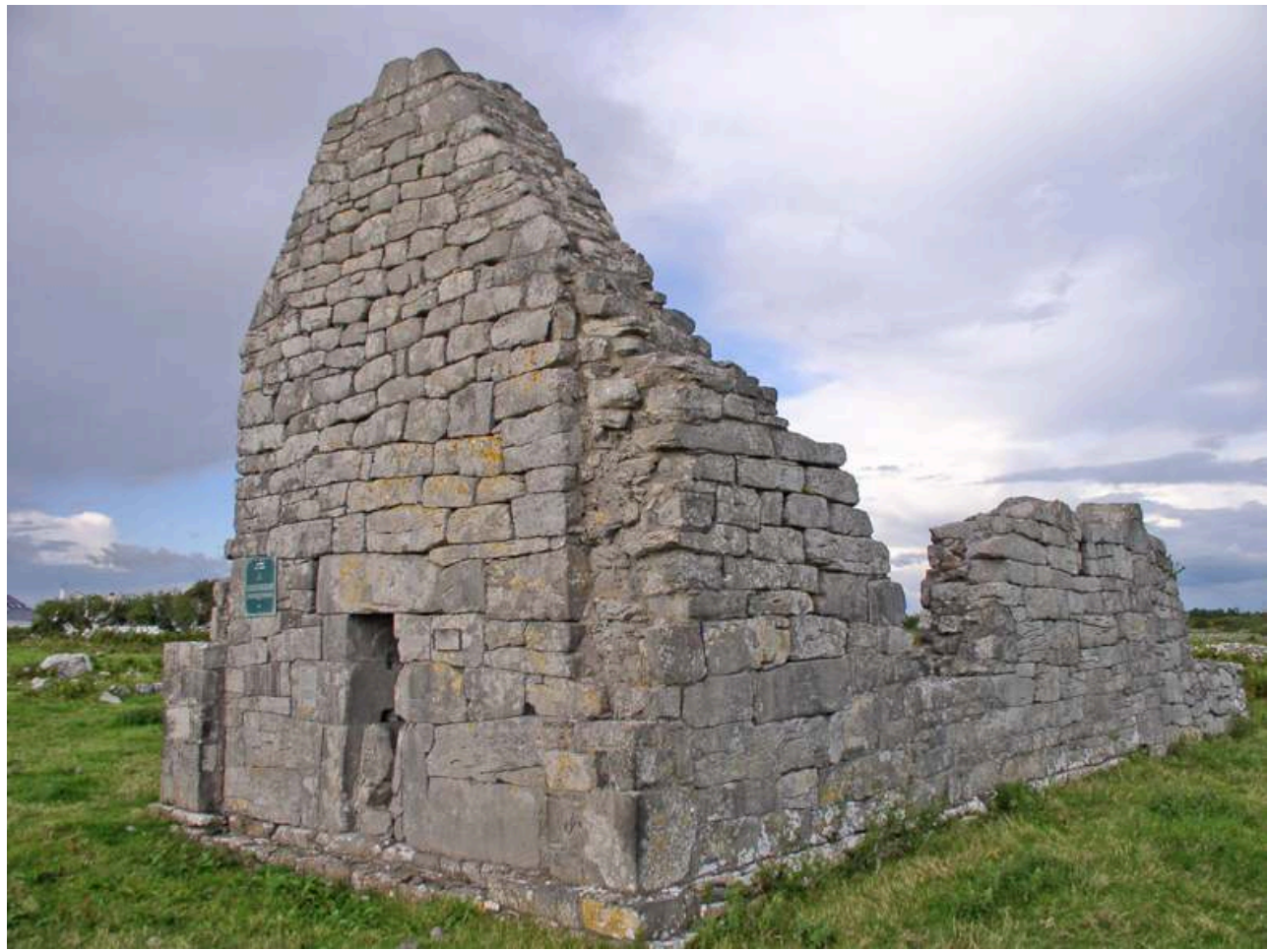

Some of these clusters of churches are characterised by subtly distinct masonry styles ; and this has been interpreted as evidence that each cluster represents the work of a particular group of masons moving between church sites in an area ${ }^{43}$. In a somewhat similar way, certain high crosses can be recognised as the work of a particular mason and their assistants : most notably the work of the so-called « Muiredach Master » at Monasterboice, Durrow, Clonmacnoise and Kells (fig. 7) ${ }^{44}$. 
Fig. 7 - East face of the head of the early tenth century Muiredach's Cross, Monasterboice (Photo T. Ó Carragáin).

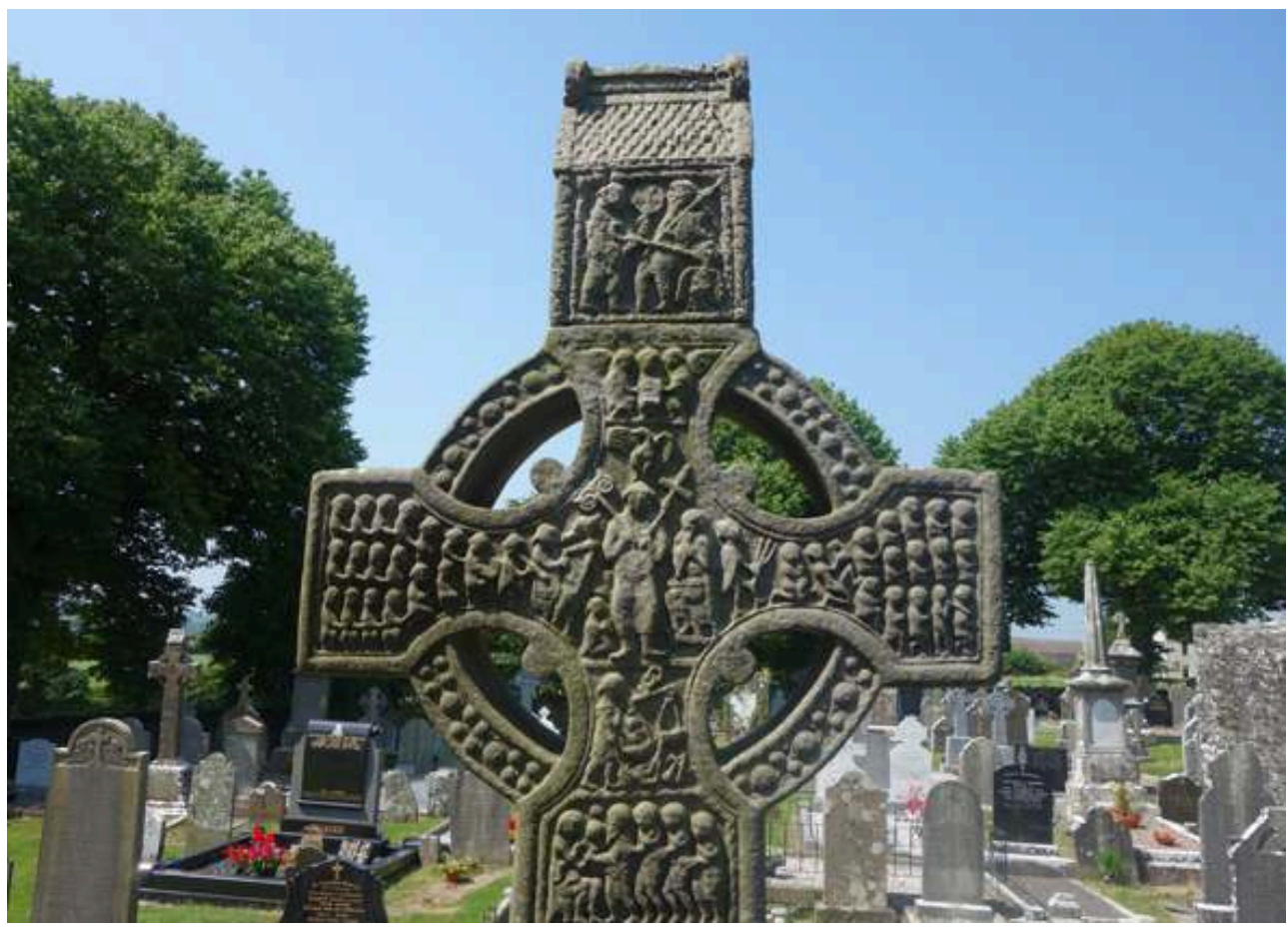

This is not surprising in the case of such once-off commissions and it is doubtful whether such a craftsman should be described as itinerant. Rather someone like the Muiredach Master - who was possibly in religious orders : below - probably travelled occasionally between major sites to execute specific commissions, presumably at the request of their communities and (often common) patrons.

\section{The resident craftsperson}

The evidence from sites like Clonmacnoise and Clonfad suggests that important monastic sites accommodated skilled craftspeople on a permanent or semi-permanent basis, perhaps in addition to peripathetic craftspeople for shorter periods. But what was the character and status of these people and what was their relationship to the religious community? At major Carolingian monasteries most of the industrial and craft activity, along with the agricultural labour, was carried out by people considered to be members of the laity. In contemporary sources some of them were known as provendarii and collectively they were referred to as a familia ${ }^{45}$. Some of these lived within the monastery (the familia intus) and their accommodation is depicted on the Plan of St Gall. They were characterised by various levels of servitude and freedom: some renounced their personal property and income upon entering the monastery while others retained one or both. Unlike these, the lay dependents who lived on the monastery's outlying estates (the familia foris) could marry and raise a family.

Important Irish churches, too, had a wide range of dependents, tenants and clients of varying status corresponding roughly to various grades of unfree and free clients in the secular sphere ${ }^{46}$. While they often had some rights over the lands they farmed, they had to pay food-render and labour services to the church, in return both for resources and pastoral services. The texts dealing with these arrangements generally speak in 
terms of the numbers of days owed by the dependent (manach) rather than detailing the particular tasks that could be assigned to them. It is not surprising, therefore, that there is no mention of craftworking in Etchingham's detailed discussion of these texts ${ }^{47}$; but it is quite possible that, on occasion, such labour services were a means by which churches could have particular craft and industrial activities carried out. Such ecclesiastical tenants were often married and seem to have farmed lands at a distance from the church. The terminology used for them is monastic, however: they are manaig (from monachus), and were expected to live by relatively strict rules in what Etchingham describes as a paramonastic existence. From an archaeological point of view, this could make them difficult to distinguish from monks on the basis of criteria such as diet, which might be expressed in the environment record ${ }^{48}$. It also brings into question the appropriateness of the term «laity» for such people. Indeed those who renounce a secular life and give themselves over to a church are often referred to as exlaymen (athláech) ${ }^{49}$. Charles-Edwards has questioned the validity of a clear-cut distinction between «monk » and " monastic tenant » : in all likelihood we are dealing with a spectrum of categories, the boundaries between which may sometimes have been blurred ${ }^{50}$. Nonetheless, in broad terms, these manaig correspond to the familia of « lay people » which one finds at Continental monasteries.

21 The Triads of Ireland intimates that " a handicraft in the same house with the inmates " is not something one should find at a church site ${ }^{51}$, suggesting that a clear distinction should be maintained between craft-workers and monks. There is an eleventh-century reference to the workshop (cerdchae) of a comb-maker at Kildare in the Fragmentary Annals ${ }^{52}$. The twelfth-century Life of Fionnchú of Brigown recounts how the saint develops his church as a metalworking centre, renaming it Brigown (« Hill of the Smiths ») and giving local smiths "the gift of handiwork provided that they should perform or begin it there ${ }^{53}$ ». On the whole, however, there is relatively little published documentary evidence for lay craftspeople or even manaig in permanent residence at monastic sites. Indeed the paucity of such evidence led Etchingham to conclude that " it is not clear that craftsmen constituted a resident, and socio-economically (as distinct from culturally) significant class at church sites ${ }^{54}$ ». This conclusion must be set against excavation evidence from a growing number of sites. For example, in light of the hagiography cited above, it is interesting that excavations on the periphery of Brigown uncovered an enclosure associated with iron-working, while another ironworking site, specialising in the production of bells - somewhat smaller than those produced at Clonfad -, has been uncovered at nearby Gortnahown, which seems to have been on Brigown's ecclesiastical estate ${ }^{55}$.

To date the most extensive evidence for craft activity from an Irish ecclesiastical complex comes from Clonmacnoise, especially in and around the residential area excavated by Heather King east of the main ecclesiastical complex - the "New Graveyard » excavations. In Hiberno-Scandinavian Dublin plot boundaries suggest that, from the tenth century, craft-workers had some personal claim over their workshops. They were more akin to citizens than to serfs; and certainly from the twelfth/ thirteenth century deeds refer to craftspeople who owned property ${ }^{56}$. By contrast, despite the considerable density of buildings, there were apparently no property boundaries in the excavated sector of Clonmacnoise, though one example of a rectangular building built over the foundations of a circular one is interpreted by King as evidence for "continuity of house plots " ${ }^{57}$. The absence of boundaries hints that those living there were different in character and status to the citizens of Dublin ${ }^{58}$. It 
suggests, perhaps, that they were manaig and that this area is comparable in some respects to the artisanal quarters at Continental monasteries; though another possibility is that some or all of them were fully-committed monks (below).

\section{Gendered craft activities and the question of female residents}

23 In either scenario, and in contrast to a "typical » urban environment such as HibernoScandinavian Dublin, one might - based on the Continental evidence - expect women to be excluded or at least marginalised and segregated to some extent. By the end of the early medieval period Clonmacnoise had at least one and possibly two satellite nunneries, the principal one located at a distance from the main complex, several hundred metres east of the area excavated by King in the New Graveyard. In early medieval documents from Ireland and elsewhere, the craft activity most closely associated with women, including nuns, is textile production. Indeed, on the basis of hagiography, Bitel concluded that « religious women, like laywomen, spent much of their time producing cloth for men ${ }^{59} »$. On the Continent, both documentary and archaeological evidence suggest that textiles were not usually produced within male monasteries, but rather by women at textile workshops some distance away, though some fulling and sewing were carried out at the monastery ${ }^{60}$. The clearest indicator of textile work in the Irish archaeological record is the spindle whorl, an item which, along with the distaff, was considered a quintessentially female object ${ }^{61}$. It is therefore perhaps suggestive - though I would put it no more strongly than that - that only one spindle whorl is mentioned in the eight published summary accounts of the Clonmacnoise New Graveyard excavations, despite the abundance of other artefacts listed ${ }^{62}$.

Segregated burial has already been highlighted as a way of helping to determine whether or not a church site was monastic in character (above). Another possible way is the analysis of activities such as spinning and textile production which, according to documentary and art historical evidence, were gendered in early medieval times. This theme deserves more attention than we can give it here, but some support for the possibility that there may be archaeological correlates in the Insular world for the Continental evidence cited above comes from the Scottish male monasteries of Portmahomack and Inchmarnock, for in both cases the only spindle whorls found related to the later medieval/post-medieval re-occupation of these sites ${ }^{63}$. On the other hand, the apparently all-male communities of Illaunloughan and Skellig Michael both produced spindle whorls, albeit in very small numbers : three and two respectively ${ }^{64}$. Bernadette McCarthy has explored the implications of these finds and has made the interesting suggestion that at these sites spinning contributed to the creation of a distinct monastic identity that was to some extent genderless as well as celibate ${ }^{65}$. It might be suggested, though, that more extensive evidence for spinning is more likely to indicate the presence of women at a site. The minor church site of Caherlehillan, Co. Kerry, produced a much larger collection of spindle whorls (39) ${ }^{66}$. While this is not surprising given its location in an area particularly suited to sheep-rearing, might we also interpret it as evidence that it might not be a male monastery but a mixed community or even a nunnery? Due to poor bone preservation we do not know the sex of those buried at the site. We know that children were buried there, but obviously the 
presence of children does not necessarily diminish the possibility that a site was monastic, as Illaunloughan and Inchmarnock illustrate, nor does it help in determining whether it was a male or female establishment ${ }^{67}$. Caherlehillan's close proximity to a substantial secular settlement could be interpreted as lending weight to the idea that it was a female establishment, for in documentary sources female religious are more likely to be depicted as remaining close to home and kin, and this is borne out by examples of nunneries "twinned" with high status secular settlements in the kingdoms of Fir Maige and Uí Fáeláin ${ }^{68}$. Some of the other activities that took place at the site are not usually associated with women, for example the modest amount of iron-working. It is worth noting, however, that substantial evidence for iron-working was found at Ballyvourney, Co. Cork, the foundation of the female saint, Gobnaid, whose name derives from gabha, "smith" ${ }^{69}$. No conclusive interpretation can be reached, but while Caherlehillan might have housed a community of female religious, it is safer to follow the excavator, John Sheehan, who has suggested that it was a family church with both male and female residents ${ }^{70}$.

\section{The monastic craftsperson}

This brings us to the issue of the involvement of monks and clerics in craft activity. As we have seen, Continental sources indicate that some industrial activities were often carried out by lay servants, but there is also plenty of evidence for monastic craftspeople. For example, Notger of St Gall (c.950-1022) mentions that specialised crafts, such as glass and bell-making, could be carried out by monks ${ }^{71}$. This has obvious implications for Clonfad. Indeed, as Tim Young points out, the style of brazing for which evidence was found at Clonfad was described in detail by Theophilus Presbyter (flourished c.1070-1125), who was clearly a metalworker and probably also a Benedictine monk ${ }^{72}$.

There is, in fact, quite a lot of Irish documentary evidence for monastic/clerical labourers and craftspeople, in contrast to the limited evidence for resident "lay » craftspeople at monastic sites ${ }^{73}$. Texts such as the seventh/eighth century Penitential of Cummean speak of, not just servile manaig but also those in clerical orders, engaged in labour as part of their monastic discipline ${ }^{74}$; while the Vitae Columbae refers to " monks who knew the blacksmith's craft " ${ }^{75}$. Legal texts imply that church buildings were sometimes built by lay craftspeople (above), and this is echoed in the hagiographical episodes relating to the mythical master-craftsman, the Gobbán Saer. In many other saints' lives, however, it is the monks themselves who build the church ${ }^{76}$. Returning to fine metalwork, the late seventh-century writer, Tírechán, recounts a story of two sons fighting over the land inherited from their coppersmith father until Patrick came along and made them donate it to him, after which : « He founded there a church, and in that place is the craftsman Cúanu, a brother of Sachellus, bishop of Baisclec ${ }^{77}$. » Presumably Cúanu was a monk or cleric as well as a craftsman. Another figure in Patrician hagiography is Bishop Assicus, Patrick's bronze/coppersmith, who made altar plate including, supposedly, patens that were at Armagh, Elphin and Saul in Tirechán's day ${ }^{78}$. Conlaed, first bishop of Kildare, was regarded along with two other bishops, as one of the three great goldsmiths of Ireland ${ }^{79}$, and, appropriately enough, in the late seventh century his remains were kept on the right side of the altar of 
Kildare in a shrine decorated with «a variegation of gold, silver, gems and previous stones ${ }^{80} »$.

There has been a certain amount of ambivalence in modern scholarship about the possibility that literate monks were involved in fine metalworking or other crafts themselves. A false dichotomy is sometimes introduced between the design and manufacture of an object. For example, one author interpreted the assembly marks on the Derrynaflan Paten, which include a number of letters, as a « clear indication of the interaction of craftsman and literate supervisor, or patron ${ }^{81} »$. Here the letters are associated with the design process, even though their purpose was to assist in the manufacturing process. Griffin Murray, however, has convincingly shown that this dichotomy is unnecessary and anachronistic, and cites a range of evidence including the inscriptions that one finds on ecclesiastical metalwork from the tenth century onwards ${ }^{82}$. For example the craftsman recorded on the inscription of the early eleventh century shrine of the Stowe Missal was 'Donnchadh Ua Taccain of the community of Cluain', probably Clonmacnoise. The metalworker responsible for, among other pieces, the early twelfth century Cross of Cong was Máel Ísu (« Servant/ Devotee of Christ ») mac Bratáin Uí Echach, a name form often indicative of someone in religious orders. As Stalley has suggested in the case of some of their stone equivalents ${ }^{83}$, Murray is surely correct to argue that the often subtle iconography of these pieces, the purpose of which was to encourage ruminatio, may in some cases be a reflection of the religious training of these craftspeople and their firsthand experience of the religious life ${ }^{84}$.

\section{Conclusion}

There is abundant evidence that lay people spent time at monastic sites for various reasons and in various capacities; and, as we have seen, archaeological evidence at a handful of sites allows us to speculate where such visitors might have stayed and how they might have interacted with the monastic community. The documentary evidence for resident lay people is, however, much more meagre ; and clearly the archaeological evidence for craft-working at ecclesiastical sites cannot automatically be taken as evidence that lay people lived there on a permanent basis. The dependents of monasteries (manaig) correspond broadly to the familiae of "lay people " associated with monasteries on the Continent. Again, however, the documentary evidence that they lived permanently within ecclesiastical/monastic complexes is quite slight. Nevertheless, it seems eminently possible that they were responsible for some of the craft activity uncovered at sites like Clonmacnoise. On the other hand, given the relatively abundant documentary evidence for monastic craftpeople, it is equally possible that some of this activity was carried out by fully-committed religious. Along with a range of other evidence outlined elsewhere (cited above), this calls into question aspects of the "monastic town » model. While a few major church sites experienced considerable nucleation, on current evidence it is not particularly useful to characterise them as burgeoning urban centres with substantial populations of lay craftspeople and traders. In its day, this model represented an important advance in our understanding of major ecclesiastical complexes, for prior to its development these sites were often written about as if they were wholly monastic islands of asceticism which had little to do with the surrounding population ${ }^{85}$. Increasingly, as we continue 
to seek more nuanced understandings of major ecclesiastical complexes, the 'monastic town' label seems to constrain more than it enables ; but we owe the proponents of this model a great debt for bringing to the fore the role of these sites as centres with crucial economic as well as religious functions.

\section{Acknowledgements}

For stimulating discussion/correspondence and for permission to refer to work in advance of publication I would like to thank Bernadette McCarthy, Griffin Murray, John Sheehan, Martin Carver, Heather King and Roy Flechner. This paper draws on research that was undertaken as part of the Making Christian Landscapes Project which was funded by the Heritage Council through the INSTAR programme.

\section{NOTES}

1. See for example R. SHARPE, "Some problems concerning the organization of the church in early medieval Ireland», in Peritia, 3 (1984), p. 230-270 ; C. Етснingham, Church organisation in Ireland, AD 650 to 1000, Maynooth, 1999.

2. T. Ó CARRAGÁIN, Churches in early medieval Ireland: architecture, ritual and memory, New Haven, 2010, p. 215-255.

3. C. ETCHInGHAM, Church organisation..., op. cit., p. 457.

4. For example C. DOHERTY, "The monastic town in early medieval Ireland ", in H. B. CLARKE and A. SIMMS (eds.), The comparative history of urban origins in non-Roman Europe, Oxford, 1985, p. 45-75; J. BRADLEY, "The monastic town of Clonmacnoise", in H. KING (ed.), Clonmacnoise studies, t. 1 (seminar papers, 1994), Dublin, 1998, p. 42-56.

5. M. VAlante, "Reassessing the Irish "monastic town" ", in Irish Historical Studies, 31 (1998), p. 1-18; C. SWIFT, «Forts and fields : a study of "monastic towns" in seventh and eighth century Ireland ", in Journal of Irish Archaeology, 9 (1998), p. 105-125 ; C. ETCHINGHAM, " The organization and function of an early Irish church settlement : what was Glendalough », in C. DOHERTY, L. DORAN and M. KELLY (eds.), Glendalough : city of God, Dublin, 2011, p. 22-53.

6. J. HENNING, «Early European towns. The development of the economy in the Frankish realm between dynamism and deceleration AD 500-1100", in ID. (ed.), Post-Roman towns, trade and settlement in Europe and Byzantium, Berlin, 2007, p. 3-40 at p. 17-21.

7. R. Ó FloINN, «The "Market Cross" at Glendalough ", in C. DOHERTY, L. DORAN and M. KELLY (eds.), Glendalough : city of God, Dublin, 2011, p. 80-111 at p. 103-104.

8. T. Ó CARRAGÁIN, Churches in early medieval Ireland..., op. cit., at p. 219.

9. See, for example, L. BITEL, Isle of the saints. Monastic settlement and Christian community in early Ireland, Cork, 1990, p. 194-221.

10. For example, T. Ó CARRAGÁIN, "The view from the shore : perceiving island monasteries in early medieval Ireland », in Hortus Artium Medievalium, 19 (2013), p. 21-33 at p. 28-29.

11. E. PURCELl and J. SHEEHAN, «Viking Dublin : enmities, alliances and the cold gleam of silver ", in D. HADLEY and L. TEN HARKEL (eds.), Everyday life in Viking towns: social approaches to towns in England and Ireland, c. 800-1100, Oxford, 2013, p. 35-60 at p. 52-53.

12. For discussion see, for example, T. Ó CARRAGÁIN, Churches in early medieval Ireland..., op. cit., p. $58,217$. 
13. J. O'Sullivan and T. Ó CARRAGÁIn, Inishmurray. Monks and Pilgrims in an Atlantic Landscape, Cork, 2008, p. 316-341.

14. J. W. MARShall and G. RouRKe, High Island: an Irish monastery in the Atlantic, Dublin, 2000, p. 50-51.

15. A. HAYDEN, «Early medieval shrines in north-west Iveragh : new perspectives from Church Island, near Valentia, Co. Kerry », in Proceedings of the Royal Irish Academy, 113 (2013), p. 67-138 at p. 101-102.

16. L. BITEL, Isle of the saints..., op. cit., p. 202.

17. B. MCCARTHY, Monasticism and its limits : Rematerialising Monastic Space in Early Medieval Ireland, Unpublished PhD Thesis, University College Cork, 2013, p. 356-370.

18. T. Ó CARRAGÁIN, Churches in early medieval Ireland..., op. cit., p. 263-268.

19. T. Ó CARRAGÁIN, Survey and Excavations at Toureen Peakaun, Co. Tipperary, Unpublished Stratigraphic Report for the National Monuments Service, Dublin, 2008 ; T. YounG, Evaluation of archaeometallurgical residues from Toureen Peakaun, Co. Tipperary, Unpublished Report for the National Monuments Service, Dublin, 2010.

20. R. Ó FloINN, "Clonmacnoise : art and patronage in the early medieval period », in C. BOURKE (ed.), From the Isles of the North: Early Medieval Art in Ireland and Britain, Belfast, 1995, 251-260.

21. M. CARVER, Portmahomack: Monastery of the Picts, Edinburgh, 2008, p. 119-125.

22. P. STEVEnS, "Clonfad - an industrious monastery », in P. STEVENS and J. CHANNING, Settlement and community in the Fir Tulach kingdom : archaeological excavation on the M6 and N52 road schemes, Bray, 2012, p. 109-136.

23. A. CONNON, "History of the early medieval kingdom of Fir Tulach», in P. STEVENS and J. CHANNING, Settlement and community..., ibid., p. 25-48 at p. 45.

24. P. STEVens, «Clonfad... », op. cit., p. 117-121.

25. P. STEVENS, « Clonfad... », ibid., p. 124.

26. P. STEVENS, « Clonfad... », ibid., p. 118, 129-130.

27. P. STEvens, "Clonfad...", ibid., p.126-131; T. Young, «Metallurgical Report» (no page numbers), in P. STEVENS (ed.), N6 Kilbeggan to Kinnegad Dual Carriageway: Archaeological Resolution. Final Report. Site: Clonfad 3, Clonfad Townland, Co. Westmeath. Vol. 2, Section 8.1, in P. STEVENS and J. CHANNING, Settlement and community..., op. cit., CD-ROM Appendices.

28. P. STEVEnS, « Clonfad... », op. cit., Fig. 8.13.

29. H. KING, "The economy and industry of early medieval Clonmacnoise : a preliminary view », in N. EDWARDS (ed.), The Archaeology of the Early Medieval Celtic Churches, Leeds, 2009, p. 333-349 at p. 336-338.

30. P. STEVens, "Diet and environment in the early medieval period", in P. STEVEnS and J. CHANNING, Settlement and community..., op. cit., p.137-152 at p.141; A. O'Sullivan et al., Early medieval Ireland AD 400-1100. The evidence from archaeological excavations, Dublin, 2013, p. 177.

31. For example A. Collins, "Settlement in Ulster 0-1000 AD ", in Ulster Journal of Archaeology, 31 (1968), p. 53-58 at p. 56-57.

32. L. LAING, The archaeology of Celtic Britain and Ireland, London, 1975, p. 245.

33. I. HODDER, Symbols in action: ethnoarchaeological studies of material culture, Cambridge, 1982, p. 59-68.

34. D. A. BinchY, Corpus Iuris Hibernici (5 vols.), Dublin, 1978, 2333.23-29; U. O'MEADHRA, Early Christian, Viking and Romanesque Art, Stockholm, 1987, at t. 2, p. 168.

35. J. Ní GHRÁDAIGH, «A legal perspective on the saer and work-shop practice in pre-Norman Ireland ", in R. MOss (ed.), Making and Meaning in Insular Art, Dublin, 2007, p. 110-125 at p. 113.

36. U. O'MEAdHra, Early Christian..., op. cit., t. 2, p. 168. 
37. R. FLECHNER, A study, edition and translation of the Hibernensis, with notes, Dublin, forthcoming, at $\S 32.5,32.6,42.6$; R. Flechner pers. comm.

38. J. Ní GHRÁdAIGH, « A legal perspective... », op. cit., p. 111-113.

39. L. Bitel, Isle of the saints..., op. cit., p. 200.

40. J. White MARSHALL and C. WALSH, Illaunloughan Island: an early medieval monastery in County Kerry, Bray, 2005, p. 22.

41. M. RYAN, Studies in medieval Irish metalwork, London, 2002 (an article originally published in 1988), p. 252.

42. B. MCCARTHY, Monasticism and its limits..., op. cit., p. 474.

43. T. Ó CARRAGÁrn, « Habitual masonry styles and the local organisation of church building in early medieval Ireland », in Proceedings of the Royal Irish Academy, 105c (2005), p. 99-149.

44. R. StAlLeY, "Artistic identity and the Irish scripture crosses", in R. Moss (ed.), Making and Meaning in Insular Art, Dublin, 2007, p. 153-166; ID., "Irish sculpture of the early tenth century and the work of the "Muiredach Master' : problems of identification and meaning ", Proceedings of the Royal Irish Academy, 114c (2014), p. 1-39.

45. W. HORN and E. BORN, The plan of St Gall : a study of the architecture and economy of, and life in, a paradigmatic Carolingian monastery, Los Angeles, 1979, t. 1, p. 341-344 ; A. VERHULST, The Carolingian economy, Cambridge, 2002, p. 72-73.

46. For example, C. DOHERTY, "Some aspects of hagiography as a source for Irish economic history ", in Peritia, 1 (1982), p. 300-328 at p. 313-315 ; C. SWIFT, "Forts and fields...", op. cit., p. 109 ; C. ETCHINGHAM, Church organisation..., op. cit., at p. 380-392, 422.

47. C. ЕTCHINGHAM, Church organisation..., ibid., at p. 408-411.

48. For discussion of possible environment evidence for a monastic diet see E. MURRAY and F. McCormick, "Environmental analysis and food supply », in J. W HITE MARSHALl and C. WALSH, Illaunloughan Island..., op. cit., p. 67-80.

49. C. ETCHINGHAM, Church organisation..., op. cit., at p. 295-298.

50. T. CHARLES-EDWARdS, "The church and settlement ", in P. Ní CHATHÁin and M. Richter (eds.), Ireland and Europe : the early church, Stuttgart, 1984, p. 167-178 at p. 171-175.

51. K. MEYER, The triads of Ireland, London, 1906, p. 9.

52. C. DOHERTY, «The monastic town... ", op. cit., at p. 67.

53. W. STOKES, Lives of saints from the Book of Lismore, London, 1890, at p. 235.

54. C. ETCHINGHAM, « The organization and function... ", op. cit., at p. 47.

55. M. CARROLL, «Archaeological excavation at Brigown, Mitchelstown, Co. Cork (03E1153) », in Unpublished report for John Purcell Archaeological Consultancy, 2005 ; T. YounG, « Archaeometallurgy report ", in J. KIELY and J. O'DONOGHUE, "Prehistoric activity and early medieval settlement site with iron working. Gortnahown 2, Co. Cork, 2011, p. 222-286. Eachtra Journal Issue 10 (eachtra.ie/ index.php/journal) ; T. Ó CARRAGÁIN, « The archaeology of ecclesiastical estates in early medieval Ireland : a case study of Fir Maige ", in Peritia, 23, in press.

56. U. O'MEADHRA, Early Christian..., op. cit., at t. 2, p. 168.

57. H. KING, « The economy and industry... », op. cit., at p. 344.

58. A late eleventh-century charter in the Book of Kells mentions a piece of property owned by a precious metalworker somewhere in the vicinity of Kells, but we probably should not attempt to extrapolate too much about the role or status of craftspeople at monastic sites from this single and relatively late source. See C. ETCHINGHAM, "The organization and function... », op. cit., p. 46-47.

59. L. BITEL, Land of women. Tales of sex and gender from early Ireland, Cornell, p. 185.

60. A. VERHULST, The Carolingian..., op. cit., at p. 75 ; V. GARVER, Women and aristocratic culture in the Carolingian world, Cornell, Chapter 5. 
61. J. Ní GHRÁDAIGH, "Mere embroiderers? Women and art in early medieval Ireland », in T. MARTIN (ed.), Reassessing the Roles of Women as "Makers " in Medieval Art and Architecture, Leiden/ Brill, 2012, p. 93-128 at p. 104.

62. H. KING, "New Graveyard at Clonmacnoise " Summary account of excavation carried out in 1992 [http://www.excavations.ie]. No spindle whorls are mentioned in the other reports (1991, $1993,1994,1995,1996,1997,1998)$. The artefacts from this excavation have not yet been analysed so the excavator was not able to confirm whether the apparent paucity of spindle whorls suggested by the summary reports is an accurate reflection of what was found (Heather King pers. comm. 14-04-2014). Even if it is, one could not, of course, conclude for certain that this area of Clonmacnoise was characterised by segregation according to gender.

63. Martin Carver pers. comm. 14-04-2014. He believes it possible that there were few or no women living at Portmahomack for at least part of the period c. AD 700-1000. C. LowE, Inchmarnock. An early historic island and its archaeological landscape, Edinburgh, 2008, p. 237.

64. J. White MARShall and C. WALSH, Illaunloughan Island..., op. cit., at p. 193 ; J. FranKLin, «The small finds ", in E. BOURKE, A. HAYDEN, and A. LYNCH (eds.), Skellig Michael, Co. Kerry: the monastery and South Peak. Archaeological stratigraphic report, 1986-2010, Dublin, 2011, p. 349-368 at p. 365.

65. B. MCCARTHY, Monasticism and its limits..., op. cit., at p. 487-488.

66. J. SHEEHAN, «Caherlehillan, Corcu Duibne : some ritual, domestic and economic aspects », in M. POTTERTON and C. CORLETT (eds.), The early Irish church in the light of recent excavations, Bray, forthcoming; J. Sheehan pers. comm.

67. C. LOWE, Inchmarnock..., op. cit., at p. 257-263 ; J. White MARSHALL and C. WALSH, Illaunloughan Island..., op. cit., at p. 84-85.

68. T. Ó CARRAGÁIN, "The view from the shore... », op. cit., at p. 26 ; P. GLEESON and T. Ó CARRAGÁin, "Conversion and consolidation in Leinster's royal heartland", in T. Ó CARRAGÁIN and S. TURNER (eds.), Making Christian Landscapes in Atlantic Europe. Conversion and Consolidation in the Early Middle Ages, Cork, forthcoming. Note in particular discussion of Cell Corpnatan, a nunnery at the royal caput of Naas.

69. Ó RIAIN, A dictionary of Irish saints, Dublin, 2011, p. 368-369.

70. J. SHEEHAN, «Caherlehillan, Corcu Duibne... », op. cit.

71. J. HENNING, « Early European towns... », op. cit., at p. 19-20.

72. T. YounG, « Metallurgical Report... », op. cit.

73. For a general discussion see L. BITEL, Isle of the saints..., op. cit., p. 128-136.

74. C. ETCHINGHAM, Church organisation..., op. cit., p. 411-415.

75. R. SHARPE, Adomnán of Iona, Life of St Columba, London, 1995, p. 178.

76. T. Ó CARRAGÁIN, Churches in early medieval Ireland..., op. cit., at p. 149-152.

77. L. BIELER, The Patrician texts in the Book of Armagh, Dublin, 1979, p. 148-149 ; M. RYAN, Studies in medieval..., op. cit., p. 252.

78. L. BIELER, The Patrician texts..., ibid., p. 140-141.

79. Ó RIAIN, A dictionary..., op. cit., p. 223-234.

80. S. CONNOLlY and J.-M. PICARD (eds.), "Cogitosus : Life of Saint Brigit », in Journal of the Royal Society of Antiquaries of Ireland, 117 (1987), p. 11-27, § 35 ; see also the Annals of Ulster, AD 800.

81. M. BRown, " "Paten and purpose", the Derrynaflan paten inscriptions ", in R. SPEARMAN and J. HIGGITT (eds.), The Age of Migrating Ideas, Edinburgh, 1993, p. 162-167 at p. 164.

82. G. MURRAY, "The makers of church metalwork in early medieval Ireland : their identity and status ", in J. HAWKES (ed.), Making histories : proceedings of the sixth international conference on Insular art, York 2011, Donnington, 2013, p.162-173. The evidence for monks as metalworkers had previously been discussed by M. RYAN, Studies in medieval Irish..., op. cit., p. 248-249.

83. R. STALLEY, «Irish sculpture of the early... », op. cit., p. 2. 
84. G. MURRAY, "The makers of church metalwork... ", op. cit., p. 169-172.

85. For example, J. RYAN, Irish monasticism : origins and early development, London, 1931.

INDEX

Index géographique : Irlande

Mots-clés : artisan

Keywords : craftsperson

\section{AUTEUR}

\section{TOMÁS Ó CARRAGÁIN}

University College Cork 